\title{
Korkut Tuna Sosyolojisinde Şehir
}

\author{
DOI: 10.26466/opus.777793
}

\author{
Enes Battal Keskin * \\ * Dr. Öğr. Üyesi, Bursa Uludağ Üniversitesi, Bursa/Türkiye \\ E-Posta: eneskeskin@uludag.edu.tr \\ ORCID: $\underline{0000-0001-5629-0228}$

\section{Öz}

Korkut Tuna, Türk sosyolojisi içerisinde İstanbul Ekolü'ne mensup önemli bir sosyologdur. Şehir sosyolojisi, bilgi sosyolojisi, Türk sosyolojisi alanlarında özgün eserler vermiştir.Tuna'nın sosyolojik yaklaşımı, yaşadı̆̆ı coğrafyanın ve tarihin birikiminden beslenmektedir. Onun sosyolojisinde şehir, avrupamerkezci bakışın dışında ve karşısındadır. Korkut Tuna, günümüzde şehir konusunun sanayi devrimi üzerinden ele alındı̆̆ına dikkat çekmektedir. Bu çerçevede Batı dünyasının gelişim süreci içerisindeki bir devrimden hareket edildiğini vurgulamaktadır. Böylece Batı şehrine dair bilginin evrenselleştirildiğini dile getirmektedir.Yüzyıllar boyunca Doğu'ya özgü olan şehri, yalnızca birkaç yüzyıl önce meydana gelen sanayi devrimi üzerinden tanımlamak büyük bir hatadır. Ona göre Doğu'da ve Batı'da iki farklı şehir anlayışı bulunmaktadır. Merkezi birliğin de etkisiyle ilk şehirler, Doğu'da ortaya çıkmış, zamanla Batı dünyasına yayılmıştır. Şehirlerin yayğnlaşmasında, Doğu ve Batı arasındaki ilişkilerin belirleyiciliği bulunmaktadır. Doğu'da şehirler, kendi iç dinamiklerinin sonucu ortaya çıkmıştır. Batı'da ise şehirler, Doğu ile ilişki kurabildikleri oranda ortaya çıkmıştır. Başka bir ifadeyle dış bir unsurun etkisiyle ortaya çıkabilmiştir. Batı dünyasının getirmiş olduğu açıklama, kendi şehirleri için geçerli olup, evrenselleştirilemez. Bu bağlamda şehir konusu, tek bir sosyoloji anlayışı tarafindan üretilmiş bilgilerle açıklanamaz.

Anahtar Kelimeler: Korkut Tuna, şehir, doğu-batı, yerli sosyoloji, tarihsel sosyoloji. 


\title{
City in Korkut Tuna Sociology
}

\begin{abstract}
Korkut Tuna is an important sociologist belonging to Istanbul School in Turkish sociology. He has produced original works in the fields of city sociology, knowledge sociology and Turkish sociology. The sociological approach of Tuna is fed by the accumulation of the geography and history in which it lives. In his sociology, the city is outside and across the eurocentric view. Korkut Tuna draws attention to the fact that today the city issue is handled through the industrial revolution. In this context, he emphasizes that a revolution is taking place in the development process of the Western world. Thus, he states that the information about the Western city has been universalized. It is a great mistake to describe the city, which was unique to the East for centuries, through the industrial revolution that occurred only a few centuries ago. According to him, there are two different city concepts in the East and the West. With the influence of the central union, the first cities emerged in the East and spread to the Western world over time. In the spread of cities, the relations between East and West are deterministic. Cities in the East have emerged as a result of their internal dynamics. In the West, cities have emerged as far as they can relate to the East. In other words, it was able to emerge under the influence of an external element. The explanation brought by the Western world is valid for its own cities and cannot be universalized. In this context, the subject of the city cannot be explained by the information produced by a single understanding of sociology
\end{abstract}

Keywords: Korkut Tuna, city, east-west, native sociology, historical sociology. 


\section{Giriş}

Korkut Tuna, Türkiye'de şehir sosyolojisine hâkim kuramsal bilgide "aktarmacılık" ya da uygulamalı çalışmalarda belli yöntem ve teknikler arasına s1kıştırılmış saha araştırmalarına dayalı kısa ömürlü çalışmalar yerine kalıcı eserler vermiş bir sosyologdur. Şehir konusunda Batı dünyasında üretilen teorileri eleştiriye tabi tutup, onların üstüne yeni açıklamalar getirmiş olması onu diğer sosyologlardan ayırmaktadır. Tuna'nın yaklaşımı, yaşadığı coğrafyanın ve tarihin birikiminden beslenmektedir. İlber Ortaylı'dan esinlenerek Türkiye'de şehir sosyolojisi çalışanlar, başka tarif bilmediklerinden dolayı Batı dünyasının tüm kavram ve kurumlarını kendi şehirlerine giydirmeye çalışmaktadırlar. Böyle bir ortamda Tuna'nın şehir konusunda yazdıkları paha biçilmezdir.

Akademik hayatı boyunca şehir sosyolojisi, bilgi sosyolojisi, Türk sosyolojisi gibi alanlarda özgün eserler veren Korkut Tuna bu çalışmada şehir konusundaki düşünceleri ile yer almaktadır. Kuşkusuz insan zihninde düşünceler birbirinden farklı ve ayrı kompartımanlar şeklinde yer almadığından, her bir fikir diğerini etkilemekte ve ondan etkilenmektedir. Bu bağlamda Tuna'nın şehir hakkındaki fikirleri, diğer düşüncelerinden bağımsız düşünülemez. Bazı makalelerinde ön çalışmasını yaptı̆̆ı, Batılı Bilginin Eleştirisi kitabıyla zirveye taşıdığı; Batılı bilgiye eleştirel bakış, Doğu-Batı ayrımına dayalı yaklaşım tercihi ve tarihsel-yerli sosyolojiyi önceleyen fikirleri şehir konusuna yaklaşımının da temelini oluşturmaktadır.

Türkiye'de şehir sosyolojisi alanında tercüme kitapların baskın bir ağırlığı bulunmaktadır. Telif eserlerin sayısının azlığı, bu konuda eser vermiş kişileri daha önemli kılmaktadır. Sosyolojik bilginin toplumların bilgisi olduğu dikkate alındığında, bilgiyi üretmenin anlamı ve değeri bir kez daha ortaya çıkmaktadır. Bu bağlamda Korkut Tuna'nın eserleri önemli bir boşluğu doldurmaktadır. Fikirlerinin özgünlüğüne ve önemine karşın Tuna'nın eserleri yeterince bilinmemekte, akademik çevrede hakettiği oranda yer almamaktadır. Bu çalışma, Korkut Tuna'nın şehir hakkındaki düşüncelerini anlamaya, önemini vurgulamaya ve şehir sosyolojisi çalışanların dikkatlerini Tuna'nın eserlerine çekmeyi hedeflemektedir. 
Korkut Tuna'nın şehir konusundaki düşüncelerini esere dönüştürdüğü kitabı Toplum Açıklama Girişimi Olarak Şehir Teorileri ${ }^{1}$ adını taşımaktadır. Bu eser aynı zamanda yazarın doçentlik tezi olarak hazırladığı iki eserin biraraya getirilmesi ile oluşturulmuştur. Tuna'nın şehir hakkındaki düşünceleri farklı boyutlarıyla Oya Okan ve Köksal Alver tarafından ele alınmış ve incelenmiştir. Korkut Tuna'nın şehir hakkındaki düşünceleri üzerine yazılmış ilk makale Oya Okan'ın Şehir, Tarih, Sosyoloji: Korkut Tuna'nın Şehir Yaklaşımı adlı çalışmadır. Okan'ın yazısının ana konusu, Korkut Tuna'nın Şehirlerin Ortaya Çıkışı ve Yaygınlaşması Üzerine Sosyolojik Bir Deneme başlıklı çalışmasıdır. Bu çalışmanın geniş bir özetini veren yazar, Türkiye'de kent/şehir çalışmaları ve araştırmaları içerisinde Tuna'nın farklılığını ortaya koyma çabasındadır (2011, s.305-328). İkinci makale Köksal Alver'e aittir; makale Korkut Tuna ve Şehir Sosyolojisi başlığını taşımaktadır. Alver bu makalede Korkut Tuna'nın şehir sosyolojisi alanındaki çalışmalarını ve bu alana katkısını incelemektedir. Ona göre Tuna, şehir sosyolojisi çalışmalarında belli bir bakış açısinı önemsemektedir (2011, s.331-346).

Bu çalışmanın ana konusu da Korkut Tuna'nın şehir üzerine düşünceleridir. Ancak çalışma Tuna'nın bu konudaki fikirlerinin temeline inerek, dahil olduğu sosyoloji geleneği ile birlikte fikirlerinin oluşum sürecindeki olay ve kişilere de yer vermektedir. Böylece Tuna'nın fikri zemininin daha iyi kav-

\footnotetext{
${ }^{1}$ Tuna akademik gelişimini şu şekilde dile getirmektedir: "Akademisyenler doçent olabilmek için bir doçentlik tezi sunmak zorundaydılar. Ben de Fransa'da iken geliştirdiğim şehir teorileri üzerine olan çalışmamı doçentlik tezi olarak sundum. Bu çalışmaya başlarken, dört beş kitaplık seri bir şehir çalışmaları düşünmüş̧üm. Önce tarihte şehirlerin ortaya çıkışı, şehirlerin gelişimi, şehirlerin günümüzdeki problemleri gibi konuları içeriyordu. Bir de şehri artı ürün açısından açıklamaya çalışan teorik bir çalışma tasarlamıştım. Bu düşüncelerimi doçentlik tezimin girişinde yazmıştım. Jüri üyeleri, fakülteye telefon edip konuyla ilgili başka bir çalışmam olup olmadığını sorgulamışlar. Ne zannettiler bilmiyorum. Belki de girişte yazdıklarımı, bir koyundan birkaç post çıkaracağım şeklinde anladılar. Her neyse, çalışmamı reddettiler. Doçentliğe böyle bir çalışmaya başvurduğumda, doçentlik başvurularında artık 'tez'le başvurma zorunluluğu kaldırıldığı ve pek çok akademisyenin birkaç makaleyle -hatta bazıları reddedilen eserlerinin bölümlerini ayrı ayrı yayınlamak suretiyle- başvurup başarılı bulunduğu bir ortamda çalışmamın kabul göreceğini düşünüyordum. Son doçentlik tezlerinde birisiydi benimki. Jüri çalışmamı reddedince ben de Ankara'ya gidip bütün üyelere teker teker giderek neden reddettiklerini sordum. Tatmin edici bir cevap alamadım. Sinirlendim ve bıraktım. Bir gün Orhan Türkdoğan geldi, niçin başvurmuyorsun dedi. Hocam dedim, ne uğraşacaksınız falan. Başvurmam konusunda ısrar etti. Peki deyip çalışmaya yeniden döndüm. Yeni bir çalış̧ma tasarladım. Önceki çalışmamın ilk kısmını biraz daraltıp, daha önceki tasarımda ikinci kitap olarak düşündügüm şehrin tarihteki geliş̧imini irdeleyen çalışmamın başına yerleştirdim. Böylelikle ortaya, şehir konusundaki kitabım çıktı. O eserle yeniden doçentliğe başvurdum. Bu sefer başarılı bulundum" (Bulut-Arlı, 2008, s.343-344).
} 
ranması mümkün olmaktadır. Bu bağlamda ilk önce Korkut Tuna'nın içerisine dahil olduğu ve katkı sunduğu İstanbul Üniversitesi Edebiyat Fakültesi Sosyoloji Bölümü namı diğer İstanbul Ekolü'nün sosyolojik düşünce geleneği hakkında bilgi verilecektir. Ardından Tuna'nın sosyolojisinin özelliklerinden bahsedilecektir. Son olarak Korkut Tuna'nın şehir konusundaki düşünceleri ile çalışma sona erdirilecektir.

\section{İstanbul Üniversitesi Sosyoloji Geleneği}

Korkut Tuna'nın düşüncelerinin şekillenmesinde, akademik hayatının geçtiği İstanbul Üniversitesi Sosyoloji Bölümü'nün sosyolojiye bakış ve ele alış tarzı önemli bir etkiye sahiptir. Tuna'nın içerisine dahil olduğu ve önemli katkılar sağladığı İstanbul Üniversitesi Edebiyat Fakültesi Sosyoloji Bolümü, Türkiye'de sosyolojik düşüncenin üniversite düzeyinde ortaya çıktığı ilk yerdir. Bu bölüm, Türkiye'de sosyolojinin bir disiplin olarak yerleşmesine önayak olmanın ötesinde daha da önemli sayılabilecek bir nitelik olarak özgün bir sosyolojik düşünce geleneğinin öncüsü ve temsilcisi bir kürsü özelliği taşımaktadır. Türk sosyolojisinin önemli isimlerinin sosyolojik yaklaşımları söz konusu geleneğin bir parçasını oluşturmaktadır (Parvin, 2011, s.47).

Sosyolojinin Batı dünyasında ortaya çımış, Batı'nın belli başlı sorunlarına çözüm arayışının bir parçası olduğu düşünüldüğünde, sosyolojik bilginin başka coğrafyalara aynen taşınmasının belli sorunları beraberinde getireceğ $\mathrm{i}$ muhakkaktır. Dolayısıyla toplumların kendi özellikleri ve tarihlerini dikkate alınarak sosyolojik bilgiyi üretmeleri büyük önem taşımaktadır. İstanbul Ekolü, bu tarz bir sosyolojinin temsilcisi durumundadır. İstanbul ekolünün sosyoloji anlayışı için; yerli sosyoloji, milli sosyoloji, tarihsel sosyoloji şeklinde isimlendirmeler yapılsa da bu ekolün temel yaklaşımı için makro ölçekli tarihsel ve eleştirel sosyoloji demek yerinde olacaktır. Ziya Gökalp ile başlayan tarihsel sosyoloji anlayışı, Baykan Sezer ile yeni bir anlayışa kavuşmuş ve Korkut Tuna'nın özgün katkılarıyla sürdürülmüştür (Alan, 2015, s.82). İstanbul Üniversitesi Edebiyat Fakültesi Sosyoloji Bölümü'nün sosyolojik bakış açısı ve sosyolojiye yaklaşımı diğer bölümlerden oldukça farklıdır. Başka bir ifadeyle, bu bölüm, sosyolojiye yaklaşım ve Türkiye'deki sorunları değerlendirmesiyle ayrıcalıklı bir konuma sahiptir. Türk toplum ve düşünce tarihine yönelik çalışmalarıyla tarihsel misyonunu sürdüren İstanbul Üniversitesi Sosyoloji Bölümü'nün, Batı sosyolojisine yaklaşımı, Doğu-Batı toplumlarının 
tarihsel farklılık ve çatışmalarına yönelik teorik çalışmaları ile diğer bölümlerden ayrılmaktadır (Kaçmazoğlu, 2002, s.332). Batı'nın dünyada hakim güç olduğu zamandan itibaren, ötekileştirmenin adı Doğu'dur. Bu bağlamda Doğu-Batı ayrımı toplumları anlamanın ve açiklamanın bir aracı konumundadır. Türkiye'nin ilk ve uzun zaman tek sosyoloji bölümü olan İstanbul Üniversitesi Edebiyat Fakültesi Sosyoloji Bölümü bu çalışmalarda önemli yer tutmuş, Doğu Batı ilişkileri ekseninde temellendirdiği sosyoloji anlayışı ile toplumlar arası ilişkiler çerçevesinde Türk toplumunun imkân ve gücünü ortaya koymaya çalışmıştır (Tuna, 2015a, s.11).

Türkiye' de yapılan sosyolojinin belli aşamaları ve özellikleri İstanbul Üniversitesi Edebiyat Fakültesi Sosyoloji Bolümü mensuplarının sosyolojiye yaptıkları katkılarla biçimlenmiştir. Bu çerçevede üç ismi özellikle hatırlamak gerekmektedir: Ziya Gökalp, Hilmi Ziya Ülken ve Baykan Sezer. (Tuna, 2013b, s.111). Korkut Tuna, İstanbul Üniversitesi Sosyoloji Bölümünün tarihinde üçüncü kuşağa mensup bir sosyologdur (Coşkun, 2011, s.28). Türk sosyoloji tarihinde İstanbul ekolünden bahsedilecekse, bu ekolün önemli bir halkasını da Tuna'nın oluşturduğunu belirtmek gerekmektedir. Tuna'nın sosyoloji çalışmaları, İstanbul ekolünün bir gelenek olarak varlığını sürdürmesinde ve yeni anlayışlar kazanmasında önemli bir etki oluşturmuştur (Alan, 2015, s.71, 79).

Bu düşünce geleneğinin ilk ismi kurumsal olarak sosyolojinin kendisiyle başladığı kabul edilen Ziya Gökalp (1876-1924)'tir. Ona göre sosyolojinin biri evrensel diğeri ulusal iki farklı boyutu vardır. Evrensel sosyoloji, medeniyetleri ve kültürleri karşılaştırır, toplumların tabi oldukları kanunları bulmaya çalışır ve bu kanunlar ışığında toplumlara yön verir. Ulusal sosyoloji ise, ulusların ortak özellikleri, toplumunun kimliği ve temel özellikleri üzerinde durur. Bu bağlamda Gökalp kurmaya çalıştığı ulusal ya da milli sosyoloji ile bir yandan Türk toplumunun yeni kimliğini ve bu kimliğin genel özelliklerini açıklamaya diğer yandan bu yeni kimliğin toplumsal yapıda yer etmesine çabalamıştır (Koyuncu, 2014, s.75). Ziya Gökalp “benim sosyolojim hem teliftir hem de tercümedir" ifadesini kullanmaktadır. İlk kitaplarında Durkheim sosyolojisinden yararlanmıştır. Gökalp yer yer Durkheim'den tercüme yaparak ayn ifadeleri kullanırken, diğer yandan da sosyolojisini Türk toplumuna ve Türk tarihine uygulayarak orijinal fikirler ileriye sürmüştür. (Tuna, 2015a, s.9). 
Türkiye'de hem sosyolojik düşüncenin hem de tarihsel sosyoloji yapma tarzının akademik olarak başladığı ve sürdürüldüğü yer İstanbul Üniversitesi Edebiyat Fakültesi Sosyoloji Bölümü'dür. Başka bir anlatımla İstanbul Üniversitesi Edebiyat Fakültesi Sosyoloji Bölümü'ne hakim sosyoloji anlayışı, Kıta Avrupası kaynaklı makro ölçekli tarihsel referansların ağır bastığı bir sosyoloji anlayışıdır. Ziya Gökalp'in çalışmaları nihai noktada tarihsel birikimleri merkeze alan ve toplumsal yapının bileşenlerini özgünlükleriyle ortaya koyan makro ölçekli toplumsal bünye çalışmalarıdır. Gökalp'in çalışmalarıyla biçimlenen sosyolojik düşünce güzergahı, kendisinden sonra gelen akademik kadrolara bir düşünce geleneğini oluşturmanın imkanlarını miras olarak bırakmıştır (Parvin, 2011, s.48-50,53). Tarihsel sosyoloji, tarih ile sosyoloji arasında ortak bir girişimi temsil etmektedir. Birlikte kullanıldıklarında bu iki disiplinin kuvvetli bir sinerji oluşturduğu fikrine dayanmaktadır. Tarihsel sosyoloji, belirli bir kuram ya da kuramsal kavramlar seti ile değil, daha ziyade toplumların incelenmesinde hem metodoloji ile ilgili meseleler hem de problemlerin seçimi hakkında genel bir yaklaşımı ifade etmektedir (Özdalga, 2011, s.9).

Gökalp'in Türk ve Osmanlı arasında gerçekleştirdiği ayrım; onun, tüm sosyolojisine damgasını vuracak olan Kültür ve Medeniyet ayrımı için gerekli olan imkanı da sağlamış görünmektedir. Ona göre Osmanlı bir medeniyetin ifadesidir. Türklük ise daha çok bir kültüre işaret etmektedir. Osmanlı devresini kapatmış ve terk edilmesi gereken bir medeniyeti gösterirken, Türklük ise yeni açlımlara izin verecek bir kültür temeline işaret etmektedir. Ziya Gökalp'in sosyolojisinden ve temelde Doğu Batı ayrımına dayanan bu ayrımlar zaman için çok geçerli olmuş karşılaştı̆̆ı sorunların çözümünün yeni bir medeniyet dairesine girmesiyle elde edilebileceğine inanılan Türk milletinin Avrupa medeniyeti içinde alması yargısını ortaya çıkarmıştır (Tuna, 2005, s.2). Doktorasını İstanbul Üniversitesi Edebiyat Fakültesi Sosyoloji Bölümü'nde yapmış olan Hüsamettin Arslan Ziya Gökalp'in Kültür ve Medeniyet ayr1mına dair düşüncelerine itiraz etmektedir. Gökalp'in medeniyet ile hars arasında yaptı̆̆ı ayrım, günümüzde savunulabilir bir ayrım değildir. Kültür ile medeniyet, hem belirsiz kavramlardır hem de reel hayatta kültür ile medeniyeti birbirinden ayırmak imkansızdır. Evrim teorisi, kuantum teorisi yalnızca bilim değildir, aynı zamanda kültürdür. Bunlar her ne olursa olsun iktidar ilişkileri dışında şeyler değildir. İktidar ve iktidar ilişkileri kavramları Gö- 
kalp'in medeniyet ve hars kavramlarından daha açıklayıcıdır çünkü hem medeniyeti hem de kültürü izah etmektedir (2018: 95). Bu bağlamda Korkut Tuna'nın da eserlerinde iktidar ve egemenlik ilişkilerine özellikle vurgu yaptığını belirtmek gerekmektedir. Bilime duyulan saygı ve güvenden yararlanarak bilim adına hareket ederken başka ilişkilerin gözden saklanabileceği veya maskelenebileceği gerçeğini unutmamak gerekmektedir. Batı'nın ayakta kalabilmek için belli bir sömürü ilişkisine bağlı olması, Batı-dışı ülkelerle bu sömürüyü sürdürecek ilişkiler kurmak zorunda oluşu bilgi ve bilimlerinin de bu amaca hizmet etmelerini zorunlu kılmıştır. Bilimin tek başına bir gücü yoktur. Bütün kimliğini ve etkinliğini emrine girdiği, hizmetine koşulduğu ilişkiler çerçevesinde kazanmaktadır. Bu bakımdan bilimin salt kendisi olarak değil içinde yer aldığı ilişkiler çerçevesinde değerlendirilmesi gereklidir. Bu ilişkiler egemenlik ilişkileridir (Tuna, 2013b, s.84, 2015b, s.188,177).

Bu düşünce geleneği içerisinde özellikle bahsedilmesi gereken bir diğer isim ise Baykan Sezer(1939-2002)'dir.2 İstanbul Üniversitesi Edebiyat Fakültesi Sosyoloji Bölüm başkanlığı da yapmış olan Sezer'e göre; sosyoloji, Batı'nın genel dünya görüşünün bir parçasını oluşturması nedeniyle bağımsızlığ 1 söz konusu değildir. Sosyoloji, 19.yüzyılda Batı ülkelerinin tarihinin ve toplumsal koşullarını ürünüdür. Sosyoloji, tarihin anlaşılması, bilinmesi ve tarihten gerekli derslerin çıkarılması çabasından başka bir şey değildir. Her sosyolog eğer mesleğine saygisı varsa tarih bilmek zorundadır (2011, s.23,31,39, 40). Korkut Tuna'nın sosyolojisi hem İstanbul Üniversitesi Sosyoloji Bölümü geleneğinden hem de Baykan Sezer' in teorisinden ayrı olarak değerlendirilemez. Korkut Tuna'nın çalışmaları Baykan Sezer'in teorisine bir ekol niteliği kazandırmıştır. (Aysoy, 2013, s.106). Tuna'ya göre; Baykan Sezer'le birlikte sosyolojinin gerçek bir tarihi zemine oturtularak, Türk toplumunun meselelerinin toplumlararası ilişkiler boyutunda bir Doğu/Batı ekseninde ele alındığı görülür. Sosyoloji böylece gerçek kimliğine kavuşmuştur denilebilir (2013b, s.111). 1977 yılında Sosyoloji Bölümü'nde asistan olarak göreve başlayan, yıllar sonra Sezer'in emekliliği akabinde bölümün başkanlığını da yapan Korkut Tuna'nın içinde görev yaptığı bölümde hakim olan

\footnotetext{
2 "Korkut Tuna ve Baykan Sezer arasında akademik yaşama dair ilginç bir durum bulunmaktadır. O dönem istanbul Sosyoloji Bölüm Başkanı Cahit Tanyol'un teklifi ile Korkut Tuna bölüme asistanlık başvurusunda bulunmuş, fakat kadroya alınamamıştır. Tuna için düşünülen bu asistanlık kadrosuna ise Baykan Sezer alınmıştır" (Bulut ve Arlı, 2008, s.334).
} 
tarihsel sosyolojik düşünce geleneği, bütün çalışmalarının kuşatıcı çerçevesini oluşturmaktadır. Başka bir ifadeyle Ziya Gökalp'ten ve özellikle Baykan Sezer'den uzanan düşünce çizgisinin izini ve etkisini Korkut Tuna'nın çalışmalarında da çok açı bir şekilde görmek mümkündür. Bu çerçevede Batı kaynaklı bilimsel bilginin tarihsel ve toplumsal evrenden hareketle değerlendirilmesi Tuna'nın düşünce dünyasındaki ana eğilimlerini yansıtması açısından dikkat çekmektedir (Parvin, 2011, s.52).

\section{Korkut Tuna Sosyolojisi}

Tuna'nın sosyolojisi, Avrupamerkezci bakışın karşısında, doğu-batı ayrımına dayalı yaklaşım içerisinde ve tarihsel-yerli sosyoloji çerçevesinde izah edilebilir. Batıll-Avrupamerkezci Bilgiye Eleştiri Tuna sosyolojisinin temel özelliğidir. Bugün bütün dünya bir merkezden yayılan ve tarihte belli ilişkilerle elde edilmiş bir bilgi türünün işgali altında bulunmaktadır (Tuna, 2013b, s.42). Toplumlar üstü olarak kabul edilen bu tür bilgilerin aslında Batılı, Batılılaştırılmış bilgiler olduğu görülmektedir. Bu bilgiler aynı zamanda hazır, düşünülmüş ve kabul edilmesi gereken bir dünya sunmaktadır. Evrensellik adına tüm toplumları belli bir açıklayıcı kalıp içine koyan ve bütün çözümleri de aynı reçetenin içine sıkıştıran bu bilgi anlayışının geçerliliği kadar kendisinden de kuşku duyulması gerekmektedir (Tuna, 2015b, s.10-13). Batı egemenlik biçimi, kendi meşruiyetini sağlamak adına en fazla bilgi ve bilimden yararlanmıştır. Kendi varoluş koşullarını evrenselleştirerek tüm dünyaya teşmil etmede bilim ve bilgiden daha elverişli bir araca sahip olmamıştır (Şan, 2008, s.648). Bilimin, bilimsel araştırmanın ve bilimsel bilginin, kendine özgü evrensel yöntemleri bulunduğu dogması, yalnızca bir dogma olmasının ötesinde de hiçbir anlam ifade etmemektedir. O, bir mittir. Evrensel bilimsel yöntemler yoktur, strateji ve bu stratejiye uygun şekilde kullanılan taktikler vardır. Strateji, bir düşmanı zayıflatma taktiğidir (Arslan, 1992, s.120-121). Batı'nun kendisi ve Dünya için teklif ettiği çözüm biçiminde karşılaştığı güçlükleri aşmak adına tüm Dünya'ya yaymak zorunda olduğu belli tür ilişkileri açıklamamak için bilgi, bir örtü olarak kullanılmaktadır. Böylece bilgi, Batı dünya egemenliğinin her türlü pis ve karmaşık ilişkisine bir kılıf olarak, onların haklılaştırılmasını üstlenen bir kavram olmaktadır (Tuna, 2015b, s.14). 
Mevcut şartlar açısından bakıldığında, "bilimsel bilginin evrenselliği" tezi, yalnızca, epistemik statükoyu elinde bulunduran" Batı'nın gücünün meşrulaştırılmasına hizmet etmektedir (Arslan, 1992, s.26). Batı toplumlarının kendi tarih dönemlerini ve toplum özelliklerini mutlaklaştırarak tüm toplumlar için geçerli sayılmasına yol açan sosyolojik yaklaşımlarda ideolojik bir taraf olduğu açıktır. Çünkü başlangıçta Batı toplumlarının tarihi gelişmeleri için ileri sürülen gelişme doğrultuları daha sonra abartılmış bir biçimde diğer tüm toplumlar ve tarihleri için geçerli sayılmıştır (Tuna, 2013b, s.40). Egemen Avrupamerkezci akımı temsil edenlere göre, sorunun cevabını Avrupa çoktan vermiştir. Dolayısıyla onların sloganı "var olan dünyaların en iyisi olan Batı'yı izleyiniz"dir (Amin, 2018, s.12).

Batı dünyasının ele geçirmiş olduğu dünya egemenliği onun dünyanın geri kalanından her açıdan üstün olduğu inancını da beraberinde getirmiştir. Bu çerçevede Avrupa'da ortaya çıkan ve oradan da Atlantik'in öteki kıyılarına ulaşan bir paradigma doğmaya başlamıştır. Bu paradigma, Avrupamerkezcilik olarak adlandırılabilir (Şan, 2007, s.62). Avrupalılar kendi uygarlıklarının yegane uygarlık olduğuna, bunun özgün bir uygarlık olduğuna, Avrupa'nın diğer milletlerden üstün olduğuna, başka uygarlıklardan iktibas yapmadığına, önce kendilerini inandırmışlar, sonrada egemenliklerini kalıcı hale getirmek için başkalarını inandırmaya çalışmışlardır. Zira, sömürgecilik sadece ekonomik ve politik bir kategori değil, aynı zamanda kültürel-ideolojik boyutları olan bir olgudur. Amerika, Afrika, Asya halklarının toprağını almak yeterli değildi, ruhuna da el koymak, bunun için de kültürel kimliklerini yok etmek gerekiyordu. İşte bu işi Avrupamerkezcilik denilen ideolojik kurgu yapmaktadır. Bu bağlamda Avrupa-merkezciliği; Batı Avrupalıların kendileri ve başkaları hakkında oluşturdukları düşünceler, teoriler, yakıştırmalar, hezeyanlar, safsatalar, yalanlar, tahrifatlar yığını olarak tanımlamak mümkündür (Başkaya, 2005, s.46).

Batı'da/Avrupa'da bilim adına gerçekleştiği söylenen her şey; aslında, burjuvazinin kapitalist ilişkileri oturtup sürdürebilmesi ve bunun sonucunda ortaya çıkan sanayileşmenin yaygınlaşması ile buna bağlı olarak denetimin elde tutulması amacıyla yapılmaktadır (Tuna, 2015b, s.84). Bugün dünya egemenliğini elinde tutan ve bunu sağlayan ilişkileri denetleyen Batı, bu ilişkileri ve sağladığı nimetleri paylaşmazken, bunu sağladığını iddia ettiği bilgiyi kitleselleştirmek istemesi, çelişkili bir durum ortaya çıkarmaktadır. Bu açıdan bilgi ve bilimlerin geniş halk kitlelerine yaygınlaştırılması Batı'da anlatıldığı 
gibi, bir aydınlanma, tüm dünyayı kuşatan bilime ve bilmeye karşı bir susamışlık değildir. Aksine Batılı tarzın yaygınlaştırılması sırasında ortaya çıkan veya çıkabilecek dirençleri kırmak, etkisizleştirmek için başvurulan bir yol olarak değerlendirilmelidir. Gerçekten de toplumsal sorunlarımız karşısında geçerli olacağı inanc ile başvurduğumuz Batılı bilgi kaynakları, bunlara dayalı akıl yürütme ve sonuç çıkartma biçimleri bütün iyi niyetli gayretlerimize rağmen karşılaştı̆̆ımız temel sorunların çözümünde yardımcı olamamıştır (Tuna, 2015b, s.94,98,210). Avrupamerkezci ideoloji ile sınırlandırılmış, sadece Batı sorunları çerçevesinde tasarlanan Batı sosyolojinin Batı-dışı toplumların yaralarına merhem olamamıştır. Çünkü her toplum kendi kimliğini ve sorunlarını tarih içinde yaşamış olduğu kendi özgül koşullarına borçludur (Şan-Şenkaloğlu, 2019, s.41). Kapımızı bir türlü açamadığımız bir anahtarda niçin ssrar ediyor, kilide uygun bir anahtar yerine anahtara uyacak bir kilit değişikliğine gidiyor hatta kapımızı tümden değiştirmeye kalkıyoruz? (Tuna, 2015b, s.227). Avrupa merkezci yaklaşımların beraberinde getirdiği özellikler Batı'ya ait olan her şeyin üstün olduğunu empoze ederek hızla yayılmasını sağlamıştır. Ancak Batı sosyolojisinin bu bakış tarzının, Batı-dışı toplumların sosyologları tarafından eleştirisi kaçınılmaz olmuştur. Avrupa merkezci Batı sosyolojisi, hem Batı'dan hem de Batı-dışı olarak tanımladıkları diğer farklı toplumlardan eleştiri almakla kalmayıp, Batı sosyolojisi karşısında alternatif çıkış yolları aranmasına kapı açmıştır (Şan-Şenkaloğlu, 2019, s.42).

Doğu-Batı Ayrımına Dayalı Yaklaşım Tercihi Tuna Sosyolojisi'nin ikinci bir özelliğidir. "Doğu-Batı ayrımı" uygarlık safhasında karşılaşılan problemlere Doğu ve Batı'nın ayrı ayrı çözümler getirmesinden kaynaklanan bir olgudur (Aysoy, 2013, s.107). Tüm tarihsel ve öznel niteliklerine rağmen Doğu/Batı ayrımı nesnel bir farklılığı ifade etmektedir ve bu farklılık ancak zihniyet temelinde süreklilik arz eden bir açıklamaya imkan tanımaktadır. Batı ile Doğu'yu birbirinden ayıran zihni kimlikler mevcuttur ve iki anlam dünyasını yüzyılların oluşturduğu bir zihinsel/kimliksel 'boşluk' ayırmaktadır. Batı kendini kendi dışındaki bir çevre içinde tanımlarken, farklılığın ölçütünü de kendisi saptamıştır. Bu açıdan tarih, Batı'nın kendisini dünyanın geri kalan kısmından ayırma süreci olarak okunabilir (Mapçupyan, 1998: 4849). Doğu-Batı sorunu çeşitli konular arasında, en ilgi çekicisi de olsa, herhangi bir konu değildir. Tüm konuların temelinde Doğu-Batı çatısmasının bulunduğu ve gerekli açıklamaları bize sağladığı için biz Doğu-Batı çatışması konusunu israrla gündeme getirmekteyiz (Sezer, 1998, s.44). 
Batı'nın kendi dışında toplumlarla kurmuş olduğu ilişki öncelikle egemenlik ilişkisidir. Konunun benzer biçimde ele alınması Batı'nın kendi dışındaki toplumlar üzerinde egemenlik kurma girişimlerini kolaylaştırmakta, bu girişime, en azından görünürde bir haklılık kazandırmaktadır. Bir yandan Batı yayılmacılığı Batı'nın kendi gücünün, kendi gelişmesinin doğal bir sonucu sayılmakta, öte yanda ise Batı'nın yayılmasıyla uygarlığı, evrensel gerçeği taşıma yükümlülügünü yerine getirdiği öne sürülmektedir (Sezer, 1998, s.41). Batı'nın düzeni; başından beri ortaya çıkışı, yükseliş ve düşüşleri, son olarak da Dünya egemenliğini ele geçirişi salt kendi gücünden, kendi toplum özelliklerinden kaynaklandığı tezleri ile açıklanmaya çalışılmıştır. Halbuki dünya tarihte Batı, Doğu toplumları ile ilişkilerinde var olmuş, özelliklerini ve kimliğini kazanmış, bu ilişkileri sürdürmesindeki başarısı ölçüsünde yükselme ve düşüş dönemleri yaşaması yanında, yine bu ilişkilere bağlı olarak kendi sınıflı yapısını ve bu yapıdaki değişiklikleri kazanmıştır. Bu bakımdan temel özellikleri açısından Batı'nın kendini yine kendisi ile açıklaması söz konusu olamaz(Tuna, 2015b, s.203).

Doğu-Batı çatışma teorisi bugün hızla değişen dünyada sorunlara açıklık getirirken Türk toplumuna da geçmişte kim olduğunu ve gelecekte kim olacağını açıklama imkânı vermiştir (Şan-Şenkaloğlu, 2019, s.48-49). Doğu her zaman tarihe yön veren ilişkilerin içinde olmuştur. Bu ilişkiler içinde taraftır. Toplumlar arası ilişkiler, tarihe yön veren temeli oluşturmaktadır. Onun ötesinde Batı'nın da, Doğu'nun da kendi kimlik ve özelliklerini kazanması bu karşılıklı ilişkiler içinde mümkün olmuştur. Doğu gelişmenin dışında olmadığı gibi uygarlık da Batı 'nın bir başına ve kendi iç ilişki ve çelişkileri sonucu değil, Doğu-Batı çatışmasının ürünü olmuştur (Sezer, 1998, s.44).

Korkut Tuna kendisiyle yapılan bir mülakatta sosyolojiye meyletmesinin sebeplerinden biri olarak o dönemde İstanbul Sosyoloji hocası Cahit Tanyol'un "sosyolojide Doğu-Batı kavramlarımı kullanılıyor olması" nı göstermektedir. Tanyol'un Osmanlı tarihini ele alan ve Doğu-Batı meselesini de bir şekilde tartışan yaklaşımlarından faydalanmış olsa bile sosyolojik ilgisinin Doğu-Batı çatışması ekseninde şekillenmesinde Baykan Sezer'in etkisi büyük olmuştur. 1977 yılında Tuna İstanbul Üniversitesi Sosyoloji Bölümü'ne asistan olarak başladığında Sezer aynı bölümde doçenttir. Ancak Korkut Tuna'nın Doğu-Batı çekişmesi ekseninde konuları ele alma tarzlarını zenginleştirmesinde kendi çabaları belirleyici olmuştur. Nitekim şehir sosyolojisi ve bilgi sosyolojisi alanlarında yapmış olduğu çalışmalar bu çabanın ürünleri 
olarak ortaya çıkmıştır (Şan, 2008, s.641). Tuna'nın yurt dışı ziyaretleri, doçentlik tezi olarak sunacağı, şehirlerin ortaya çıkışı ve yaygınlaşmasının tarihsel arka planını irdeleyen çalışması için gerekli araştırmaları yapma imkânı sağlamıştır. İstanbul ekolünün, özellikle Baykan Sezer'in temel yaklaşımı olan Doğu-Batı çatışması, Tuna'nın kullandığı bir yaklaşım olarak, şehir konusundaki çalışması ile iyice belirmeye başlamıştır (Alan, 2015, s.68).

Tarihsel-Yerli Sosyoloji Vurgusu Tuna Sosyolojisi'nin üçüncü özelliğidir. İçinde yaşanan koşullar her şeyden önce o toplumun tarihi/toplumsal koşullarıdır. Bunlar toplumun, toplumlararası ilişkilerin ürünüdür. Sosyoloji bu ilişkiler çerçevesinde ortaya çıkan gelişme doğrultularını, bunlara bağlı olarak ortaya çıan sorunları anlama, açıklama ve çözüm üretme çabasıdır (Tuna, 2013b, s.16). Sosyolojinin Batı'da ortaya çıkmış olması ve daha çok Batı'nın çıkarları ile paralel bir gelişim göstermesi sosyolojiye ilk başlarda bütünü ile Batı ile sınırlı sorunların dünya çapında evrenselleştirilmesi görevini de vermiş, buna paralel olarak Batı-dışı ülkelerde ortaya çıkan sosyoloji anlayışlarının temelini de bu yaklaşım oluşturmuştur. Günümüzde sosyoloji, toplumların kendi sorunlarına çözüm arama çabası ile yeni bir kulvara girmeye başlamıştır. Bu bakımdan bizim de kendi sorunlarımızı çözmede fonksiyon icra edecek ve kendi çıkarlarımız doğrultusunda geliştirilecek bir sosyolojiye ihtiyacımız bulunmaktadır (Şan, 2008, s.639-640). Sosyolojinin tarih eksenine ya da tarihe bakması bana göre bu bilimin bir zaman: ve mekân eksenine kavuşmasını sağlamaktadır. Ben altta ayağımızın dayandığı, olaylarını sistemleştireceğimiz tarihî/toplumsal ya da belli bir zaman/mekân çizgisinin olmasını hep tercih ettim. Ben ayağımın nereye bastı̆̆ını hangi dönemde hangi zaman ve mekânda olduğumu bilmeden bir söz dizesine anlam kazandırmayı veya kazandırılmış olduğunu pek idrak edemiyorum (Tuna, 2010a, s.178-179).

Tuna, klasik sosyoloji literatüründen uzak, toplumu anlama ve açıklama yolunu seçmiş bir sosyologdur. O toplumu tarihi olaylardan, vakıalardan kalkarak açıklamak istemektedir. Tuna, önünde nesnel bir olay görmeyince, tarihi ve toplumsal bir realiteyle hesaplaşmayınca bir sosyoloji yapabileceğine inanmamaktadır. Durkheim'ın ne dediğiyle ilgilenmediğini, başkalarının söylediği laflar üzerinden veya onların çizdiği yollar üzerinden bir sosyoloji yapamadığ ifade etmektedir. Tuna, olaylardan ve tarihi realitelerden, toplum gerçeğinden yola çlkarak bir şeyleri izah etmenin daha geçerli olabileceğini düşünmektedir. Kendi ifadeleriyle "Benim kafamda bir tarih, zaman ve 
mekân tutarlılığı̈̈nemli(...)Ben karşılı̆̆ıda toplumu görmediğim bir şeyde sosyoloji yapamadım(...)Sosyolojizi biraz topluma müdahale eden, toplumu dönüştürmeye mütemayil olan bir bilim olarak gördüm(...) Neticede, böyle bir sağduyu sahibi olarak toplumun genel titreşimlerini, dönüşümlerini yakalayabileceğime inandım." (BulutArl, 2008, s.345-346).

Tuna'ya göre; geçerli bilgi ve yorumlara sahip olabilmek için yapılacak ilk iş, tarihî ve toplumsal gelişmemizi yeni baştan ve kendimize özgü bir bakış açısıyla gözden geçirmektir. Bu yeniden ele alış ilk Doğu uygarlıkları ile başlayan ama Yunan ve Roma ile Batı yönüne sapan ve günümüz Batısında biten bir gelişme çizgisi içinde feodal olup olmadığımız şeklinde bir yer aramak değil, Yunan ve Roma Uygarlıkları ile kopartılıp Batı'ya çekilen gelişme çizgisinin bizim yönde kalmış ve ihmal edilmiş kısmını bulup günümüze kadar getirmek olmalıdır. (Tuna, 2013a, s.290, 293, 295, 297). Bu bağlamda sosyolojimize büyük bir görev düşmektedir: Dünyayı yeniden kurmak. Kendi açmazlarımıza, kendi çıkarlarımız doğrultusunda bir cevap bulabilmek için yeniden anlamak, yeniden tanımlamakla başlamak ama dünyayı yeniden kurmakla bitirmek (Tuna, 2013b, s.20).

\section{Korkut Tuna Sosyolojisinde Şehir}

Asıl amacı şehirlerin ortaya çıkışını ve yaygınlaşmasını açıklamak olan Tuna, literatürü gözden geçirip eleştiriye tabi tutarak hakim paradigmayı sorgulamaktadır. Bu çerçevede Pirenne, Weber, Şikago Okulu ve Lefebvre'nin düşüncelerini tartışmakta, üretilen kuramlardaki Batılı karaktere, sınırlı bilgiye ve bunun evrenselleştirilme çabasına dikkat çekmektedir. Şehri ilişkiler ağının merkezi olarak açılayan Tuna, ilk şehirlerin Doğu'da ortaya çıtığını zamanla Batı'ya yayıldığını ifade etmektedir. Doğu ve Batı'da şehirlerin farklı serüvenleri olduğunu, mevcut literatürde Doğu'nun ihmal edildiğini dile getirmektedir. Bu bağlamda şehir konusu nasıl açıklanmaktadır? ve şehir konusu nasıl açılanmalıdır? başlıkları altında Tuna'nın görüşleri ele alınarak incelenmektedir.

\section{Şehir Konusu Nasıl Açıklanmaktadır?}

Konuyu detaylandırmadan önce şehir konusunun Tuna'nın gündemine nasıl girdiğini, akademik yaşamında bu konunun nasıl bir yer tuttuğunu açıklamak anlamlı olacaktır. Korkut Tuna, 1980'de Fransa'dadır ve orada doçentlik 
çalışması olarak düşündüğü şehir konusunda kütüphanelerde araştırma yapmaktadır. Ancak Tuna, şehir üzerine çalışmaya daha önce karar vermiştir. O dönemde bir siyasi partinin seçim söylemlerinde, siyasetin artık şehir tarafından tayin edilebileceği tarzında laflar söylenmektedir. Bu laflar, Tuna'da bir çağrışım yapmış ve şehir konusunun önemli olduğunu düşünmeye başlamıştır. Baykan Sezer'le, ilk tanışmalarında Gordon Childe'in Tarihte Neler Oldu vb. kitaplarından bahsetmesi Tuna'nın şehir konusuna dikkatini daha fazla çekmiş ve şehir konusunda çalışmaya başlamıştır (BulutArlı, 2008, s.339).

Korkut Tuna'nın reddedilen ilk doçentlik tezi, Şehirlerin Ortaya Çıkış ve Yaygınlaşması Üzerine Sosyolojik Bir Deneme adı ile 1987 yılında İstanbul Üniversitesi Edebiyat Fakültesi yayınları arasında çıkmıştır. Tuna, 2011 yılında doçentlik tezi olarak sunduğu ve reddedilen bu ilk çalışması ile kabul edilen ikinci çalışmasını birleştirerek, Toplum Açıklama Girişimi Olarak Şehir Teorileri adı ile yeniden yayımlamıştır (Alan, 2015, s.68-69). Korkut Tuna şehir üzerine düşüncelerini bu kitabında net bir şekilde ortaya koymaktadır.

Tuna, şehir konusunu "sosyolojinin hesaplaşmak zorunda olduğu konulardan biri" olarak görmektedir. Toplum Açıklama Girişimi Olarak Şehir Teorileri ${ }^{3}$ bir nevi bu hesaplaşmanın eseridir. Tuna bu kitabında Batılı bilgiyi eleştirmekte, şehir konusunu Doğu-Batı kavramsallaştırması çerçevesinde açıklamaktadır. Günümüzde şehir ve şehirleşme, önem kazanmaya başladığı zamandan günümüze gelen süreç içinde, batılı yazarlarca önce bir "toplum açıklama biçimi" sonrada "topluma biçim verme aracı" olarak kullanılmıştır. Tuna'ya

\footnotetext{
3 "Benim çalışmam birçok şehir çalışması içinde bir paragrafta veya bir sayfada geçen bir dönemin bir kitap haline getirilmiş şeklidir. Yani hangi açıdan olursa olsun, şehir ve şehircilikle ilgili birçok kitapta, tarihte şehirler konusundan ya standart bir paragraf ya da bir kitap sayfası kadar bahsedilmiştir. O kısım bende bütünüyle ele alınmıştır. Yalnız eksiktir. İslam ve Osmanlı ile bitmektedir. Günümüz açısından, günümüz şehrini belki daha farklı kaynaklardan yazmak mümkündü. Ama o zaman için tam oturmuş bir şey de belki yoktu. Fransa'da biraz disiplinlerarası şehir araştırmalarında gördüğüm kadarıyla onlar da şehri tanımlamakta güçlük çekiyorlardı. Mesela, şehri kapitalizmin ürünü olarak açıklamak isteyen çalışmalar vardı. Ama bu açıklamalar Türkiye için pek geçerli gözükmüyordu...Benim çalışmamın eksik yanı şuydu: Eserde şehir planlaması ve şehir düzenlemesi ile ilgili bir bölüm var, ancak tarihsel açıklamada bir eksiklik var. Osmanlı sonrası ya da Ortaçağ sonrası Batı kentinin durumu neydi? Daha sonra kaleme aldığım 'kentsel toplum'la ilgili bir yazımda, bu soruya belki kısmen cevap veriyorum. Fakat onda da şimdinin 'küresel şehirler'i eksik. Küreselleşmenin getirdiği boyut ilave edilebilir. Ama en azından şehri zaman içinde oluşup gelişen bir sosyal varlık olarak tanımlamaya ve sistemleştirmeye çalıştım. Yani tarihî bilginin yanında sonraki bölümde onu belli unsurlarıyla bir nevi kendi arasındaki farklılığı gösteren şeyleri ele almaya çalıştım” (Bulut-Arlı, 2008: 347).
} 
göre; dünyanın almaya başladığı biçimi Batı toplumlarının şehirlerindeki gelişmelerle birlikte ve onlara bağlı olarak açklayan şehir teorileri "toplum açıklama biçimi" olarak işlev görürken, şehir planlama çalışmaları da "topluma biçim verme aracı" olarak kullanılmaktadır (2013a, s.9,171). Henri Pirenne'den başlayarak Türkiye' de şehir sosyolojisi literatüründe şehir kuramcısı olarak geçen ana aktörlerin düşüncelerini ele alarak tartışan Tuna, bu teorilerin ancak Batı dünyası için geçerli olabileceğini dolayısıyla evrenselleştirilemeyeceğini dile getirmektedir.

Pirenne, Roma İmparatorluğu'nun yıkılışının antik uygarlığın bitişi demek olmadığını ispata çalışmış, Frank-Cermenlerin istilasıyla Roma şehirleri ve kültürünün kısmi bir değişikliğe uğrayarak sürmekte olduğunu iddia etmiştir. Ona göre değişiklikteki ana etken, Akdeniz'in müslümanların eline geçmesidir. Bu olay Cermen Avrupa'sını yeni bir hayat tarzına ve yaratıcılığa sürüklemiştir. Ortaçağ Kentleri, bu süreci ve sonuçlarını ele almaktadır. Pirenne'e göre Bütün Ortaçağ boyunca şehirlerin gerçek gelişimini tüccarlar sağlamıştır. Şehir, sermaye ve hürriyet birbirinden ayrılmaz üç kavramdır ve Ortaçağ şehrinin gerçek özelliğini oluşturmaktadır (Ortaylı, 2014, s.9). Ortaylı'ya göre Henri Pirenne bir Avrupalıdır, Ortaçağ Kentleri kitabında Avrupa uygarlığının üstünlüğünü dile getirmektedir. Onun kuru ekonomizmi, içerdiği yanlışlar ve doğrularla bir çağın tarihçi kuşağını etkilemiştir (2014, s.9). Pirenne, Avrupa Ortaçağ kentlerinin ticaretin izleri üzerinde, tüccarların öncülüğünde kurulduğunu, bu gelişmelerin sanayileşmeye imkan hazırlad1ğını dile getirmektedir. Pirenne'in açıklamaIarı kentin oluşumunu tek bir faktöre ve coğrafyaya bağlama zaafını taşımakla birlikte Avrupa'da endüstri toplumunun oluşum sürecini anlamak bakımından önem taşımaktadır (Bal, 2006, s.129). Tuna'ya göre Pirenne, Batı'daki tüm gelişmelerin çıkış noktasında bulunan orta çağ şehrini; kendisini ayrıcalıklı bir birlik haline getiren bir hukuk, bir idare ve istisnaî bir yargı sahibi, ticaret ve sanayi ile uğraşan, canlı bir topluluk olarak tanımlamaktadır. Pirenne'in şehir tanımında bulunan her bir özellik daha sonra Batı toplumunu şehre bağlı olarak açıklama girişimlerinde özel anlam ve yorumlar kazandırılarak Batı şehrinin özgünlüğü ile bütünleştirilmektedir (2013a, s. 97).

Kent kuramcıları içerisinde Max Weber'in ayrı bir yeri bulunmaktadır. Weber, ilk kez 1921 yılında yayımlanan bir çalışmasında, kentin doğası, kent türleri, kentin siyasi, idari, ekonomik, hukuksal nitelikleri üzerinde durmuştur. Weber'in çalışması alanında yapılmış ilk çalışmalardan biri olması, bu 
alandaki çalışmalarda kendisine sık sık atıf yapılması nedeniyle büyük önem taşımaktadır (Bal, 2006, s.133). Weber'e göre; ne ekonomik anlamda "şehir" ne de sakinlerinin özel politik-idari yapılarla donandığı garnizon, mutlaka bir kentsel "topluluk" oluşturmaz. Tam bir kentsel topluluk oluşturabilmek için bir kentsel topluluk, alışveriş ve ticaret ilişkilerinin görece bir hâkimiyetine sahip olmanın yanısıra bir bütün olarak yerleşim alanı; kaleye, pazara, kendine ait bir mahkemeye ya da özerk bir hukuka, ilgili bir birlik biçimine, kısmi bir özerkliğe, kendi kendini yönetebilme ve sonuçta seçilmelerinde şehir sakinlerinin katılımının gerçekleştiği yetkililerce yönetilme imkânına sahip olmalıdır. Kelimenin tam anlamıyla bir kentsel "topluluk", yalnızca Avrupa'da ortaya çıkmıştır (2010, s.109). Weber'in ileri sürdügü temel tez şehir ismiyle anılan fenomenin, en kamil manasıyla Batı ya özgü ve tarihsel süreci itibariyle Batı'daki demokrasinin gelişimiyle yakından ilintili olduğu yönündedir. $\mathrm{Bu}$, bir bakıma antikitenin keşfedilmesiyle, bu keşfin gecikmesinden sorumlu tutulan Hıristiyanlığa karşı takınılan tutumun, Ortadoğu orjinli olmasından ötürü, bütün Sami dünyasına teşmil edilmesi nedeniyle, tarihî, siyasî, İçtimaî, kültürel yargılara - hasılı topyekun İnsani etkinlik alanları hakkındaki değerlendirmelere kadar sirayet eden bir eğilimin, Avrupa merkezciliğin tipik yansımalarından biridir (Aydoğan, 2000, s.9). Weber, kenti Batı'nın değerleri ve tarihinin önemli bir parçası ve tamamlayıcısı olarak özellikle vurgulamaktadır. Ona göre kent, Batı'nın Doğu dünyasından farklılı̆̆ını ortaya koyduğu sosyolojik bir dışavurumdur (Pınarcıoğlu vd., 2013, s. 77). Tuna'ya göre Weber, başka kıtaların şehirlerinde bulunmayan bir özgünlük gösterdiğini iddia ettiği Batı Şehri'ne dair düşüncesine, Batı dışı toplumları da katmış ve getirdiği yeni bir yorumla Batı şehrini başlı başına bir şehir tipi olarak diğerlerinden ayırmıştır. Weber, Batı şehrinin sahip olduğu özel bir dayanışma içindeki birlik olgusu ile yeryüzünün diğer şehirlerinden kesin bir şekilde ayrıldığını düşünmektedir. Bu yorumu ile şehir teorileri literatürüne "Batı şehri" türünün kesin bir şekilde yerleştiği ve Weber'in bu türü ortaya koyan yorumunun tartışmasız bir şekilde kabul gördüğü anlaşılmaktadır (Tuna, 2013a, s.109, 117).

Saha araştırmalarını da içermesi nedeniyle şehir sosyolojisi literatüründe ayrıcalıklı bir yeri olan Şikago Okulu'nun görüşleri ayrı bir öneme sahiptir. Bu okulun önemi, şehir konusuna ekolojik ve sosyal psikolojik bir yaklaşımla eğilen sosyologların, 1920'li yıllarda Şikago şehrinin yaşadığı hızlı değişme- 
leri belli araştırmalar çerçevesinde ele almalarından ve bunlara bağlı açıklayıc modeller oluşturulmalarından kaynaklanmaktadır (Tuna, 2013a, s.157). Bu çerçevede Şikago Üniversitesi'nde 1915-1925 yılları arasında yürütülen bir dizi tez, makale ve özel araştırmalar Şehir (The City) adlı bir kitapta toplanmiştır. Robert E. Park, Ernest W. Burgess, Roderick D. McKenzie'nin bu çalışmaları ABD' deki sistematik ilk şehir teorisinin başlangıcını oluşturmaktadır (Bal, 2006, s.145). Son zamanlara kadar, bu yüzyılın ilk yirmi yılında meşhur olan Şikago sosyoloji okulunun katkıları, kent çalışmaları hakkındaki tartışmalara egemen olma eğilimindeydi. Şikago Okulu'nun birbiriyle ilişkili iki düşüncesi, özel dikkati hak eden görüşlerdir. Biri, kentin mahallelerinin dağılımına yönelik, "ekolojik yaklaşım” olarak adlandırılan yaklaşımdır. Bu yaklaşım, biyolojideki ekolojik süreçlerle, yani bitki ve hayvan yaşamının fiziksel çevrede, o çevreye adapte olma biçimleri aracıyla düzenli bir şekilde dağıldığı süreçlerle açık bir benzerlik kurma esasında geliştirilmiştir. Şikago okuluna bağlı ikinci etkili bakış açısı, kentlerde yaşamın evrensel özelliklerini tanımlama iddiasında olan Louis Wirth'in "yaşam biçimi olarak kentsellik/bir yaşam biçimi olarak kentlilik." (Giddens, 2012, s.93-94) Kentliliği, kentin fiziksel varlığı ile tanımladığımız, onu yalnızca mekânla sınırlandırdığımız ve kentsel tutumların keyfi yasal sınırların bittiği yerde birdenbire kesileceğini düşündüğümüz sürece, bir yaşam biçimi olan kentlilik için uygun bir kavram geliştirmiş olamayız. Kentleşme, artık, yalnızca insanları kent olarak adlandırılan mekana çekme sürecini belirtmekle kalmamakta, insanların kentin yaşam biçimini benimsemesi anlamına da gelmektedir (Wirth, 2002, s.81). Onun sosyal psikolojik bir yaklaşımla ele aldığ ş̧ehir konusunu, Batı'ya özgü çağdaş bir olay olması varsayımına dayanarak; Şikago şehrinden yola çıkan araştırmalarla özdeşleşmesini sağlamıştır (Tuna, 2013a, s.164). Tuna'ya göre Şikago Okulu, bir Batı şehrinde ortaya çıkan sorunlardan hareketle geliştirilen çözüm ve açıklamalar ile kente dair tanımlamaların tüm şehirler için genelleştirilebilme iddiası nedeniyle egemen Batılı paradigmanın bir parçasını oluşturmaktadır.

Marksist bir düşünür olarak şehirlerin tarihî gelişmeleri üzerinde de görüş bildiren Lefebvre; şehri, belirli üretim ve değişim ilişkilerine bağlı olarak ortaya çıkan bir örgütlenme olarak tanımlamaktadır. O'da sanayi olayına bağlı olarak hızlı bir şehirleşmenin ortaya çıtığını ve farklı türden ilişkileri örgütlediğini tekrar etmektedir. Bununla birlikte belli bir noktadan sonra şehirleş- 
menin sanayi karşısında tayin edicilik açısından ön plana geçtiğini ileri sürmektedir (Tuna, 2013a, s.141). Lefebvre; toplumun bir bütün halinde kentleşmekte olduğunu, bir bütün halinde kentleşmeden doğan toplumu kendisinin "kent toplumu" olarak adlandırdığını ifade etmektedir. Ayrıca "kent toplumu" terimini sanayileşmeden doğan toplum anlamında kullandığını, bu yüzden kent toplumunun, tarımsal üretimi bizzat emen veya onun üzerinde hakimiyet kuran bir süreç sonucunda inşa edilen toplum anlamına geldiğini vurgulamaktadır. Böyle bir ortamda şehircilik, devletin ve politik eylemin maskesi olup, strateji ve bir sosyo-mantık içinde gizlenmiş çıkarların aracı konumundadır. Şehircilik, mekanı bir sanat eseri olarak, ya da teknik nedenlere göre değil, gerçekte politik bir amaca göre biçimlendirmeye çalışmaktadır (2017, s.7-8,168). Lefebvre, Marks'ın tanımladığı kapitalist üretim ilişkileri ve güçleri arasındaki çelişkinin kentsel mekanda farklı bir boyuta ulaştığını dile getirmektedir. Lefebvre'nin yaklaşımı içinde kentten ziyade kırdan uzaklaşmış, global, kentsel ilişkilerin kendi yaşam biçiminin egemen olduğu bir mekan bulunmaktadır Kapitalist gelişme içinde, sermaye mekanı bir meta haline getirmiş bulunmaktadır. Bahis konusu mekan kapitalist üretim ilişkilerinde yeniden üretilmektedir. Sanayiden, kent kaynaklı modern kapitalist üretime dönüşüm Lefebvre tarafından "kentsel devrim" olarak adlandırılmaktadır. Lefebvre'nin kentsel devrim kavramı kentin fiziksel mekanıyla s1nırlı olmayıp, genel anlamda bir kentli yaşam/kentte yaşam tarzını vurgulamaktadır (Aslanoğlu, 2000, s.68-69). Kentsel toplumu açıklama konusunda önemli bir aşama olarak ortaya çıkan kentsel devrim Lefebvre'e göre önemli bir ayırım özelliği taşımaktadır. Çünkü bu ayırım noktasında sonra çağdaş toplumu yönlendiren sanayileşmeye ait dönemden kentsel toplumun öne ç1kacağı bir geçilmektedir. Bir zamanlar sanayi tarafından yönlendirilen şehir şimdi yönlendirici olmaya başlamış ve kentsel olan dünya ölçüsünde etki sahibi olmuştur. Lefebvre'in bütün bu açıklamaları kentsel olayının evrenselliği noktasına ulaşmaktadır. Lefebvre'nin vardığı bu nokta ile şehir teorilerinde yeni bir boyuta ulaşıldığı görülmektedir. Var olan bütün yanları ile tüm bir toplumu ve ilişkilerini kuşatan, üstelik biline gelen özellikleri içindeki bir şehrin boyutlarını aşan kentsel olay; şehir teorilerinde alışıla gelen ve Batı'ya ait herhangi bir özellikle sonuçlanan düz bir gelişmenin dışına çıkmayarak ve bu gelişmenin kaçınılmaz bir sonucu olarak, evrensel bir özellik kazanarak karşımızda bulunmaktadır (Tuna, 2013a, s.148,151, 153,154). 
Şehir sosyolojine hakim paradigmanın ana teorileri bağlamında ele alınan bütün bu yaklaşımlar, odaklarına Batı şehrini almaktadır. Şehir teorilerinde Batı şehrinin üstünlügüünü ortaya koyma çabası bir müddet sonra ulaşılması gereken bir hedefe dönüştürülmekte ve evrenselleştirilme gayreti dikkat çekmektedir. Oysa Batı tarihinin kendine özgü gelişim süreci içinde şekillenen kent ve kent toplumu, dünyanın diğer coğrafyalarında bulunan şehirlerden üstün değil sadece farklıdır.

Korkut Tuna, şehir konusuyla bağlantılı olarak planlama ve küreselleşme kavramlarını da tartışmaktadır. Planlamaya bağlı düzenleme çalışmalarında şehre, bölgeye ve nihayet bunlar aracılığıyla topyekün bir topluma yön vermek söz konusudur (2013a, s.171). Planlama en geniş anlamıyla, ulaşılması istenen hedeflerin önceden tespit edilmesi, bu hedeflere ulaşmak için yapılması gerekenlerin belirlenmesi ve bunların düzenlenmesi süreçlerini içermektedir. Planlama, entelektüel kökenlerini aydınlanma düşüncesinden almaktadır. Bu düşünce ile rasyonel aklı olan, aklıyla bilgi üretip, ürettiği bilgiyle doğaya egemen olan bir yeni insan kavramsallaştırması ortaya çımıştır. Aydınlanma düşüncesinin entelektüel çerçevesini çizdiği planlama kavramı ise, sosyal değişmenin inşa edilebileceğine, yönlendirilebileceğine ve devamında da hedeflenene ulaşlabileceğine dair inancın somutlaşmış halini ifade etmektedir (Akçay, 2005, s.467). Tuna'ya göre; sanayileşme ile birlikte Batı Avrupa' da görülen hızlı nüfus artışı ve artan şehirleşme sonucunda ortaya çıan problemlerin büyüklüğü, sorunların kaynağı kitleleri disiplin altına almak ve onları belli yerlerde toplamak amaciyla yeni bir bilimin doğmasına yol açmıştır. Bu bilim, 1910'larda Fransa' da "Urbanisme" olarak isimlendirilmektedir ki etimolojik açıklaması şehirlerin düzenlenmesi bilimi anlamına gelmektedir. Sanayileşme sonrasında karşılaşılan problemler, bunların çözümü yolundaki girişim ve politikalar, tek tek şehirlerin planlanmasından bölgenin planlanmasına ve oradan ülkenin planlanmasına doğru bir gelişme izlemiştir. Topluma ve toplum olaylarına istenilen yönün verilmesini amaçlayan planlama girişimleri, kontrol mekanizma ve araçları üzerinde ayrıntılı bir biçimde durmuşlardır. Bilindiği üzere planlama teknik değil, tamamen siyasi bir mesele olup, planlamacılık şehircilik değil, kentsel düzende bir sosyal kontrol aracidır(2013a, s.165-168).

Tarafsız olarak ele alındığında küreselleşme, insanlar ve toplumlar arasındaki karşılıklı ekonomik, ticari, siyasi, sosyal ve kültürel ilişkilerin dünya öl- 
çeğinde yayginlaşması anlamına gelmektedir. Tarih boyunca uygarlıklar birbirlerinden yararlanmışlardır. Fakat, kapitalizm, doğasında var olan yayılma dinamiği nedeniyle sömürücü ve kutuplaştırıcı bir uygarlıktır. Başka uygarlık modelleriyle bir arada barış içinde yaşayamamakta, diğer uygarlıkları kendi işleyişinin bir gereği olarak biçimlendirmekte ve bağımlı hale getirmektedir. Eğer kapitalist üretim tarzı, doğası gereği bu özellikleri taşıyorsa, küreselleşme denilen şey de kapitalist sistemin işleyişi sonucunda ortaya ç1kan bir durum olmaktadır. Bu bağlamda küreselleşme kavramında bir orijinallik veya yenilik söz konusu değildir. Bu yüzden, küreselleşmenin insanlığa yeni imkanlar vadeden bir süreç veya olgu olarak sunulması seyirciyi oyalamaya yarayan ideolojik bir manipülasyondan ibarettir (Başkaya, 2005, s.325-326). Başka bir anlatımla küreselleşme, Batılı değer, meta ve sembollerin tedavüle girmesi ve Batı-dışı toplumlara taşınması sürecini ifade etmektedir Fakat küreselleşme paradoksal bir şekilde medeniyet idrakini güçlendiren bir etkide de bulunmaktadır. Örneğin küreselleşmenin nesnesi ve alıcısı durumunda olan toplumlar, küreselleşme dalgası karşısında emin bir direniş hattı oluşturmak için, kendi tarihlerine ve hafızalarına başvurma ihtiyacı hissetmektedirler (Kalın, 2019, s.14).

Tuna'ya göre; küreselleşmenin ortaya koyduğu yeni dünya düzeni arayışları içinde, şehir aracılığı ile tüm toplumlara istenilen yönün verilebileceği düşünülmektedir. Habitat esas adıyla "İnsan Yerleşmeleri Üzerine Birleşmiş Milletler Konferansı" çalışmalarında söz konusu edilen bir yerleşim yeri olarak şehirler vasıtasıyla yapılacak düzenlemelerle topyekün bir dünyaya istenilen yönün verilebilmesidir. Bu açıdan bakıldığı zaman küreselleşme ile şehir ve şehre bağlı düzenlemeler arasında sıkı bir bağlantı ortaya çıkmaktadır. Bu defa Batı dünyası, küreselleşme söylemi içinde daha çok kendi şehirlerinde gözledikleri ve bir şekilde çözümüne sahip olduklarına inandıkları sorunların, bu defa mevcut gelişmelere bağlı olarak kendi dışlarındaki toplumlarda da büyük boyutlarda orta çıkıp sorunlara yol açacağına inanmaktadırlar. Kendileri için de rahatsızlık kaynağı olacak birçok konunun, dünya çapında bir mesele olarak ama kendi teklif ettikleri yönde ele alınarak çözüme kavuşturulmasını teklif etmektedirler (2013a, s.171-173). Planlama, şehirlerde bir sosyal kontrol aracı işlevi görürken, küreselleşme ise, şehirler aracılığıyla tüm toplumlara şekil vermenin bir aracı olarak kullanılmaktadır. 


\section{Şehir Konusu Nasıl Açıklanmalıdır?}

Tuna şehri, ilişkiler ağının merkezi oluşuyla açıklamaktadır. Ona göre şehir, toplumların tarih içinde ulaştıkları belli bir üretim düzeyi ve bunun gerektirdiği toplumsal örgütlenmelere bağlı olarak ortaya çıkmıştır. Şehrin ortaya çıkışı, kendi dışındaki bazı toplum olay ve ilişkilerine bağlıdır. Yeni ve fazla bir toplum hasılasının ortaya çkarıldığı bu ilişkilerde; şehirler, üretim/yönetim ilişkilerinin yeniden biçimlendirilmesinde ve sürdürülmesinde ortaya çımış yeni bir toplum örgütlenmesidir (2013a, s.295, 9, 22-23). Korkut Tuna, şehirlerin, toplumlararası ilişkiler bağlamında anlaşılabileceğini ve şehirlere tarihsel gelişme içinde bakıldığında toplumların örgütlenme biçimlerine göre şekillendiklerinin görülebileceğini ifade etmektedir (Okan, 2011, s.314). İnsanların tek başına çözemedikleri sorunları, birlikte çözme adına oluşturduğu toplumsal yapı ve ilişkiler, sorunların farklılığı bağlamında farklı toplum örgütlenmeleri meydana getirmiştir. Bunlardan biri olan köy örgütlenmesi, yüzyıllarca insanların açmazlarına bir çözüm işlevi görmüştür. Köyün yetersiz kaldığı aşamada, yeni bir örgütlenme birimi olarak şehir ortaya çıkmıştır. Böylece şehir, insanların yeni sorunlarına bir çözüm olarak, hayatiyet bulmaktadır. Eğer mevcut sorunlar köy örgütlenmesi içerisinde çözülebilmiş olsaydı o zaman şehri ortaya çıkaran sebepler de oluşmamış olacaktı. Bu bağlamda şehir, tarım ve onun toplumsal örgütlenmesi olan köyde karşılaşılan problem ve açmazlara çözüm yolu olarak ortaya çıkan ilişkilerin yeni toplum örgütlenme birimi olmaktadır.

Arkeolojik bulgular ekolojik açıdan uygun yerlerde, büyük nehirlerin geçtiği verimli ovalarda yüksek nüfuslu yerleşmelerin ortaya çıktığını göstermektedir. Bu çerçevede ilk şehir yerleşimleri Doğu'da tarih sahnesine çıkmıştır (Aslanoğlu, 2000, s.14, Özcan, 2018, s.8). Doğu tarihte ilk şehirlerin oluşturulduğu uygarlığın adıdır. Bu ilk şehirler kendiliklerinden, kendi başlarına değil, kendi dışlarındaki ilişkilere bağlı olarak ve bu ilişkilerdeki sorunlara bulunmuş çözümün eseri olarak ortaya çıkmışlardır. Uzak yerler arasında ilişkilerin kurulmasına yol açan ticaret, şehir çözümünün yaygınlaşmasına da yol açmıştır. (Tuna, 2013b, s.351, 2013a, s.14, 195, 202).

Doğu ve Batı dünyasında şehirlerin gelişim süreçleri birbirinden oldukça farklı sebeplere dayanmaktadır. Toplumun ürettiği zenginliğin hem bir nedeni hem de sonucu olan devlet, Doğu'da şehir örgütlenmesiyle birlikte anılmaktadır. Devlet, şehirlerdeki zenginliğin korunmasının ve sürdürülmesinin 
teminatı olmaktadır. Şehirlerde ortaya çıkan tarım dışı üretim faaliyetleri, şehirleri aynı zamanda bir yönetim merkezine dönüştürmektedir. Dolayısıyla şehirler, idari-siyasi-askeri faaliyetlerin de örgütlendiği merkezler olmaktadır. Bu nedenlerle şehir, üretimin, zenginliğin, yönetim merkezi olmanın avantajıyla uzun bir süre yalnızca Doğu'ya has bir gelişme olarak kalmıştır. Doğu toplumlarında oluşturulan ürün fazlasının başarılı bir şekilde yönetilmesi, zaman içerisinde Doğu şehirlerindeki canlılığın Doğu dışı toplumlarında da ortaya çıkmasına neden olmuştur. Böylece Doğu dışında şehirlerin oluşum ve gelişimlerine tanık olunmaya başlanmıştır. Batı'da ise şehirler, Batı'nın dünya egemenliğinde pay sahibi olduğu, Doğu ile ilişkileri denetleyebildiği yerlerde ve dönemlerde ortaya çıkmış veya gelişme gösterebilmişlerdir. Böylelikle ilk Avrupalılar veya Batılılar olarak tanıyacağımız topluluklar Doğu uygarlıkları tarafından biriktirilen zenginliklerle doğrudan veya dolaylı bir biçimde karşılaştıklarında gelişmenin içine girmişlerdir. Ticaret ve korsanlığın bir arada yürüdüğü bu ilişkilerde Doğu şehir uygarlıklarını ihtiyaçları olan hammaddelerle beslemişler ve karşılığında kendileri için gerekli maddeleri almışlardır. Doğu toplumlarının artı-ürününe el koyan bu toplumlar kendilerinin üretemedikleri bir hasılaya dayanarak, sorunlarını çözmede bir örgütlenme içine girmişler, kendi şehirlerini ortaya çıkarmışlardır. Şehirlerin her biri kendisini besleyecek tarım alanından yoksun olması nedeniyle, kendi dışlarındaki imkanları kullanabildikleri ölçüde yaşayabilecekleri siteler şeklinde örgütlenmişlerdir. Diğer topluluklarla ilişkilerinin düzensiz hatta kopuk olması gibi sorunlardan kurtularak belirli bir besin üretimine ulaştıkları ilk aşamada, 1500 yıllık bir gecikme ile şehirli bir aşamaya ulaşmışlardır (Tuna, 2013a, s.227, 225).

\section{Sonuç}

Tuna sosyolojisinde şehir, avrupamerkezci bakışın dışında ve karşısında, doğu-batı ayrımına dayalı yaklaşım içerisinde ve tarihsel-yerli sosyoloji çerçevesinde ele alınmaktadır. Şehri bu şekilde ele alış, şehir sosyolojisine önemli bir katkı olduğu kadar, literatürdeki ezberleri bozması açısından da bir o kadar değerlidir. Korkut Tuna'ya göre; toplumların yapıları ve içinde bulundukları ilişkilerle şehirleri arasında bağlantı bulunmakta ve şehir bunlar tarafından belirlenmektedir. Her toplumun yapısı, hayatı algılayış ve yaşayış biçimi, tutum ve değerleri diğer toplumlarla arasında farklılık oluşturmaktadır. 
Şehir konusu da farklılıkların en açı şekilde kendini gösterdiği bir örgütlenme birimidir. Doğu'da ve Batı'da iki farklı şehir kurgusu bulunmaktadır. Batı dünyası, birkaç yüzyıldan beri elinde bulundurduğu, bilimsel ve ekonomik gücü kendi egemenliğini sürdürmenin aracı haline getirmiştir. Bu bağlamda şehir konusunda da literatür Batı Şehri, onun ortaya çıkışı, özellikleri ve özgünlüğü üzerinedir. Dahası gerçek şehrin yalnızca Batı'da var olduğu vurgulanmaktadır. Batı Dünyası, sanayileşmeyi merkeze alarak, bugünden geçmişe ve geleceğe doğru şehir konusunu, kendi üstünlügünü perçinlemek amacıyla yeniden ele almaktadır. Bu hikaye Batı şehrinin hikayesidir, bulunduğumuz coğrafyada şehir, Batı dünyası ile aynı güzergahı izlememiştir.

Tuna, günümüzde şehir konusunun sanayi devrimi üzerinden ele alındığını, bu çerçevede Batı dünyasının gelişim süreci içerisindeki bir devrimden hareketle, Batı şehrine dair bilginin evrenselleştirildiğini dile getirmektedir. Buna göre dünyadaki tüm şehirler, sanayileşme sonucu ortaya çıkan ekonomik ve sosyal koşullara göre tanımlanmaktadır. Yüzyıllar boyunca Doğu'ya özgü kalan şehri, yalnızca birkaç yüzyıl önce meydana gelen sanayi devrimi üzerinden tanımlamak büyük bir hatadır. Şehir, tarihi bir perspektifle ele alınıp incelendiğinde ancak anlaşılabilir ve açıklanabilir. Bu bağlamda Tuna, köy örgütlenmesinin ortaya çıan sorun ve açmazlar karşısında yetersiz kalması sonucunda ileri bir örgütlenme birimi olarak şehrin ortaya çıktığını söylemekte ve düşüncelerini Doğu-Batı yaklaşımı çerçevesinde ifade etmektedir. $\mathrm{O}$, Doğu'da ve Batı' da tarihin ve coğrafi koşulların toplumsal örgütlenme biçimleri arasında farklılıklar oluşturduğunu belirtmektedir. Merkezi birliğin de etkisiyle ilk şehirler, Doğu'da ortaya çıkmış, zamanla Batı dünyasına yayılmıştır. Şehirlerin yaygınlaşmasında, Doğu ve Batı arasındaki ilişkilerin belirleyiciliği bulunmaktadır. Doğu'da şehirler, kendi iç dinamiklerinin sonucu ortaya çıkmışken, Batı'da şehirler Doğu ile ilişki kurabildikleri oranda, başka bir deyişle dış bir unsurun etkisiyle ortaya çıkabilmiştir. Bu nedenle olsa gerek Doğu dışı dünya, şehirleşme aşamasına Doğu'yla kıyaslanmayacak derecede geç ulaşmıştır.

Batı Dünyası ele geçirdiği dünya hakimiyetini sürdürmenin bir aracı olarak şehir konusunda üretmiş olduğu bilgiyi yaymak istemektedir. Bu bağlamda Batı dışı dünyada bilgi üretiminin sınırlı olması ya da Batı dünyasından gelen hazır reçetelerin kullanılması nedeniyle, şehir konusu belirli dönem ve olaylarla bağlantılı ve sınırlı olarak ele alınmaktadır. Zamandan ve mekandan bağımsız bu bilgi, şehri kendi başına bir olay olarak sunmaktadır. 
Tuna, şehirlerin ortaya çıkışı ve yaygınlaşması süreçlerinde tarihe vurgu yapmaktadır. Ona göre, her bilgi hele şehir gibi doğrudan mekan ve insan ilişkilerine dayalı bir örgütlenme, bulunulan coğrafya ve tarih dikkate alınmadan açıllanamaz. Batı dünyasının getirmiş olduğu açıklama, kendi şehirleri için geçerli olup, evrenselleştirilemez. Bu bağlamda şehir konusu, tek bir sosyoloji anlayışı tarafından üretilmiş bilgilerle değil, her toplumun kendi gerçekleri ve çıkarları ile oluşturduğu sosyolojiler çerçevesinde ele alınmalıdır. Bu bağlamda Korkut Tuna, Batı sosyolojisi ve tarihinde toplum açıklama ve kimlik belirleme girişimlerinde yeni arayışların bulunması gibi bizim de İslâm şehri, Doğu şehri ve Türk şehri üzerinde söyleyebilecek sözlerimiz olması gerektiğini vurgulamaktadır. "Literatür ölümcüldür." Ülkemizde şehir konusunda yapılan çalışmalar dikkate alındığında bu cümle acı bir gerçek olarak karşımıza çıkmaktadır. Literatür nedeniyle Batı şehrinin ortaya çıkışını ve gelişim süreçlerini, kendi ülkesinin şehirlerinde arayan aydın tipi bu toprakların yabancısı olmadığı bir durumdur. Korkut Tuna bunun farkında olarak, şehir ve şehirleşmemizle ilgili olarak kendimize ait görüş ve yorum sahibi olmamız, kendi yaşadığımız olayları kendi gözümüzle ve çıkarlarımıza uygun bir şekilde değerlendirmemiz gerektiğini vurgulamaktadır. 


\section{EXTENDED ABSTRACT}

\section{City in Korkut Tuna Sociology \\ Enes Battal Keskin \\ Bursa Uludă̆ Üniversitesi}

In the case of Turkey it is dominated by translated books on city sociology. The low number of copyrights makes the people who have worked on this subject more important. Considering that sociological knowledge is the knowledge of societies, the meaning and value of producing knowledge is revealed once again. Despite the originality and importance of his ideas, Tuna's works are not well known and do not take place in the academic environment as they deserve. This study aims to understand Korkut Tuna's thoughts about the city, to emphasize its importance and to draw the attention of city sociology employees to the works of Tuna. Korkut Tuna's book, in which he transformed his thoughts on the city into his work, is named City Theories as a Community Explanation Initiative. This work was also created by bringing together two works that the author prepared as an associate professor thesis.

The main subject of this study is Korkut Tuna's thoughts on the city. However, the study goes to the basis of Tuna's ideas on this subject, and includes the events and people in the formation process of his ideas together with the sociology tradition he is involved in. Thus, it is possible to better grasp the intellectual ground of Tuna. In this context, firstly, information will be given about the sociological thought tradition of Istanbul University, Faculty of Letters, Department of Sociology, in which Korkut Tuna is included and contributed. Then, the features of the sociology of Tuna will be mentioned. Finally, the work will be terminated with Korkut Tuna's thoughts on the city.

In the sociology of Tuna, the city is considered outside and against the Eurocentric perspective, in an approach based on the east-west divide and within the framework of historical-indigenous sociology. Taking the city in this way is as valuable as it is an important contribution to city sociology as well as breaking the routine in the literatüre. According to Korkut Tuna; There is a connection between the structures of societies and their relations with their 
cities and the city is determined by them. The structure of each society, perception of life and lifestyle, attitude and values make a difference between other societies. The city issue is also an organizational unit where the differences are most clearly manifested. There are two different city configurations in the East and the West. The Western world has made the scientific and economic power it has held for several centuries a means of maintaining its rule. In this context, the literature on the city is also on the West City, its emergence, features and originality. Moreover, it is emphasized that the real city exists only in the West. The Western World, by focusing on industrialization, rethinks the city issue from today to the past and the future in order to reinforce its superiority. This story is the story of the Western city, in our geography the city did not follow the same route as the Western world.

Tuna states that today the city issue is handled through the industrial revolution, and within this framework, the knowledge of the Western city has been universalized based on a revolution in the development process of the Western world. Accordingly, all cities in the world are defined according to the economic and social conditions that arise as a result of industrialization. It is a great mistake to describe the city, which has remained unique to the East for centuries, over the industrial revolution that took place only a few centuries ago. The city can only be understood and explained when it is examined and analyzed from a historical perspective. In this context, Tuna states that the city emerged as an advanced organization unit as a result of the inadequacy of the village organization in the face of the problems and dilemmas and expresses his ideas within the framework of the East-West approach. He states that history and geographical conditions in the East and the West create differences between social organization forms. With the effect of the central union, the first cities emerged in the East and spread to the Western world in time. Relations between East and West have a decisive role in the spread of cities. While cities in the East have emerged as a result of their own internal dynamics, in the West, cities have emerged as a result of their relationship with the East, in other words, under the influence of an external element. For this reason, the world outside the East has reached the urbanization stage incomparably late with the East.

The Western World wants to spread the knowledge it has produced about the city as a means of maintaining its world domination. In this context, due to the limited production of knowledge in the non-Western world or the use 
of ready-made prescriptions from the Western world, the subject of the city is dealt with in a limited and limited way with certain periods and events. This knowledge, independent of time and space, presents the city as an event in its own right. Tuna, emphasizes history in the processes of the emergence and expansion of cities. According to him, every information, especially an organization based on direct space and human relations like the city, cannot be explained without taking into account geography and history. The explanation brought by the Western world is valid for its own cities and cannot be universalized. In this context, the city issue should be handled within the framework of the sociologies created by each society with its own facts and interests, not with the knowledge produced by a single understanding of sociology.

In this context, Korkut Tuna emphasizes that we should have words to say about the city of Islam, the city of the East and the Turkish city, just as new quests are found in the attempts to explain society and identity in Western sociology and history. Because of the literature, the intellectual type who seeks the emergence and development processes of the Western city in the cities of his own country is a situation that these lands are no stranger to. Korkut Tuna, being aware of this, emphasizes that we should have our own views and interpretations about the city and our urbanization, and that we should evaluate our own events in accordance with our own eyes and interests.

\section{Kaynakça / References}

Akçay, Ü. (2005). Planlama. (Ed.: F. Başkaya), Kavram Sözlüğ̈̈, Ankara: Özgür Üniversite Kitaplı̆̆.

Alan, S. (2015). Türk Sosyoloji tarihinde İstanbul ekolü: Korkut Tuna örneği. Yayımlanmamış Yüksek Lisans Tezi, Bingöl Üniversitesi / Sosyal Bilimler Enstitüsü.

Alver, K. (2011), Korkut Tuna ve Şehir Sosyolojisi. Sosyoloji Dergisi, 22(3), 331-346.

Amin, S. (2018), Avrupa-merkezcilik. İstanbul: Yordam Kitap.

Arslan, H. (1992). Epistemik cemaat. İstanbul: Paradigma Yayınları.

Arslan, H. (2018). Jöntürkler Jönkürtler Muhafazakarlar. (4.Basım)., İstanbul: Paradigma Yayinları.

Aslanoğlu, R. A. (2000). Kent, kimlikve küreselleşme. 2.Basım, Bursa: Ezgi Kitabevi. 2000. Aydoğan, A. (Haz.). (2000). Şehir ve cemiyet. İstanbul: İz Yayıncllk.

Aysoy, M. (2013). Korkut Tuna'nun Sosyolojisi üzerine. Tyb Akademi, 9, 105-118.

Bal, H. (2006). Kent Sosyolojisi. 3.Basim.Isparta: Fakülte Kitabevi. 
Başkaya, F. (Ed.),(2005). Avrupa-Merkezcilik”, Kavram Sözlüğ̈̈, Ankara: Özgür Üniversite Kitaplığı.

Başkaya, F. (Ed.),(2005). Küreselleşme. Kavram Sözlüğü içinde Ankara: Özgür Üniversite Kitaplığı.

Bulut, Y., Arlı A. (2008). Korkut Tuna ile Türk Sosyolojisinin dünü ve bugünü üzerine. Türkiye Araştırmaları Literatür Dergisi, 6(11), 327-352.

Coşkun, I. (2011). Korkut Tuna biyografisi için ilk notlar. Sosyoloji Dergisi, 22(3), 19-29.

Gıddens, A., (2012). Sosyoloji kısa fakat eleştirel bir giriş. (Çev. Ü. Yıldız Battal), 4.Basım, Ankara: Siyasal Kitabevi.

Kaçmazoğlu, H.B. (2002). Türk Sosyoloji tarihi üzerine araştırmalar. 2.Basım., İstanbul: Birey Yayınclik.

Kalın, İ. (2019), Modern barbar medeni. İstanbul: İnsan Yayınları.

Koyuncu, A. (2014). Türkiye' de Sosyoloji ekolleri. Sosyoloji Divanı, 4, 65-96.

Lefebvre, H. (2017). Kentsel deorim. (Çev. S. Sezer), 5.Basım, İstanbul: Sel Yayıncilı.

Mahçupyan, E. (1998). Doğu ve Batı: Bir zihniyet gerilimi. Doğu Batı Dergisi, 2, 45-55.

Okan, O. (2011). Şehir, Tarih, Sosyoloji: Korkut Tuna'nın şehir yaklaşımı. Sosyoloji Dergisi, 22(3), 305-328.

Ortaylı, İ. (2014). Kurumların tarihçisi Henri Pirenne hakkında. (Çev. Ş. Kradeniz), 13.Basım, Ortaçă̆ Kentleri içinde, İstanbul: İletişim Yayınları.

Özcan, G. (2018). Doğu ve Batı arasında şehir. İstanbul: Yeditepe Yayınevi.

Özdalga, E. (2011). Tarihsel Sosyoloji, 3.B., Ankara: Doğu Batı Yayınları.

Parin, S. (2011). Korkut Tuna'nın İstanbul Üniversitesi Sosyoloji bölümü tarihindeki veri. Sosyoloji Dergisi, 22(3), 47-57.

Pınarcıoğlu, Ş.P., Kanbak, A., ve Şiriner, M. (2013). Kent Kuramları. 2.Basım, Türkiye perspektifinden kent sosyolojisi çalışmaları, İstanbul: Örgün Yayınevi.

Pırenne, H. (2014). Ortaçağ kentleri. (Çev. Ş. Karadeniz), 13.Basım, İstanbul: İletişim Yayınları.

Sezer, B. (1998). Doğu- Batı ayrımı. Doğu Batı Dergisi, 2, 37-45.

Sezer, B. (1998). Sosyolojinin ana başlikları. İstanbul: Kitabevi.

Şan, M. K., (T.y). Sosyal Bilimleri yeniden kurgulamak: Avrupa-Merkezci yaklaşımların aşılması çabaları. Sosyoloji Dergisi, 3(15), 57-84.

Şan, M. K., (2008). Korkut Tuna. (Der: M.Ç. Özdemir), Cilt. 2, Türkiye'de Sosyoloji içinde (s.639-666) .Ankara: Phoenix Yayınevi.

Şan, M. K., ve Şenkaloğlu, S. (2019). Batı Sosyolojisi karşısında Türkiye'de yerli sosyoloji arayışı. Sosyal Ve Kültürel Araştırmalar Dergisi, 5(9), 35-59.

Tuna, K. (2005), Türkiye'de Sosyoloji- Ziya Gökalp sempozyumu açılış konuşması. Sosyoloji Dergisi, 3(10), 1-4. 
Tuna, K. (2010a). Türk Sosyolojisi üzerine.. (Haz.: Ç. Kovanlıkaya-E. Çav), Türk Sosyolojisinde üç bilim insanı, İstanbul: Bağlam Yayınları.

Tuna, K. (2010b). İstanbul'un Sosyolojik dönüşümü. ,(Ed. A. E. Bilgili), Şehir ve kültür: İstanbul içinde (s.357-381) .İstanbul: T.C. Kültür Ve Turizm Bakanlığı İstanbul Kültür Ve Turizm İ Müdürlüğü Yayını,

Tuna, K. (2013a). Toplum açıklama girişimi olarak şehir teorileri. 2. basım, İstanbul: İz Yayincilik.

Tuna, K. (2013b). Yeniden Sosyoloji. İstanbul: İz Yayıncllı.

Tuna, K. (2015a), Sosyolojinin Türkiye'ye gelişinin 100. Y1lı Üzerine. Sosyoloji konferanslar, No: 52 (2015-2) / 3-12.

Tuna, K. (2015b). Batılı bilginin eleştirisi üzerine. 5.basım ., İstanbul: İz Yayınclık.

Weber, M. (2010). Şehir. (Çev. M. Ceylan), 9.Basım., İstanbul: Yarın Yayınları.

Wirth, L. (2002). Bir Yaşam Biçimi Olarak Kentlileşme. (Der. ve Çev. A. Alkan, B. Duru), 20. Yüzyıl Kenti içinde (s. 77-106), Ankara: İmge Yayınevi.

\section{Kaynakça Bilgisi / Citation Information}

Keskin, E. B. (2020). Korkut Tuna Sosyolojisinde şehir. OPUS-Uluslararası Toplum Araştırmalarn Dergisi, 16(30), 3183-3212. DOI: 10.26466/opus.777793 